\title{
EXPERIMENTAL PAPER
}

\section{Preliminary study on the impact of methanolic extract of Elephantopus scaber Linn. on hair growth promoting effect in rats}

\author{
HIMANSHU BHUSAN SAHOO ${ }^{2}$, RAKESH SAGAR ${ }^{1 *}$, SUBRAT KUMAR BHATTAMISRA ${ }^{3}$, \\ AMRITA BHAIJI ${ }^{2}$ \\ ${ }^{1}$ Department of Pharmacognosy and Phytochemistry \\ Dr. H.S. Gour Central University \\ Sagar, 470003 \\ Madhya Pradesh, India \\ ${ }^{2}$ Department of Pharmacology and Toxicology \\ Vedica College of Pharmacy \\ Bhopal 462021 \\ Madhya Pradesh, India \\ ${ }^{3}$ Department of Pharmacology \\ Roland Institute of Pharmaceutical Sciences \\ Berhampur 760010 \\ Orissa, India \\ *corresponding author: e-mail: drrsagar@gmail.com
}

\section{Sum m a r y}

Methanolic extract of Elephantopus scaber leaves was investigated for its role in hair growth in experimental rats. The $2 \%$ and $5 \%$ solution of prepared formulation using methanolic extract was studied for hair growth on wistar rats for 30 days. Minoxidil (2\% solution) was taken as a reference standard. The prepared hair oil formulation of methanolic extract significantly $(p<0.01)$ potentiated the hair growth initiation and completion time with dosedependent improvement in skin biopsy, hair length and hair weight. In vitro hair follicles development study showed the significant $(p<0.05)$ improvement in the initiation of new hair follicles. Above mentioned results indicated that the methanolic extract of $E$. scaber rendered significant hair growth promotive effect.

Key words: alopecia, hair growth, Elephantopus scaber, minoxidil, MESL, methanolic extract 


\section{NTRODUCTION}

Alopecia is a dermatological disorder and distressing symptom [1]. It is common universal problem in primary healthcare practice throughout the world and has been estimated to affect both genders of all races between $0.2 \%$ and $2 \%$ of the world population [2]. It has been suggested that alopecia could have an indirect effect on psychological and social lifestyle along with self esteem among both genders [3]. The main problems associated with alopecia such as pigmentation problems (fading), dandruff and falling of hair. Regardless from metabolic and hereditary causes, alopecia has been observed as a major side effect of anticancer, immunosuppressant and many other drug treatments [4]. The root hair reflects the growth, water and nutrient uptake and site of infection by fungus which is the primary factor of alopecia [5]. Many people suffer from hair loss or hair thinning despite the development of several medical treatments. Therefore, it is important to develop a novel therapy that could prevent hair loss and enhance the hair growth [6]. The search for treatment results in few drugs of synthetic origin, but their side effects cannot be neglected [7].

Elephantopus scaber Linn. (Asteraceae) popularly known as Elephant's foot is a wild shrub distributed worldwide in all tropical regions. Phytochemically, the plant has been reported to contain sesquiterpenes lactones deoxyelephantopin, isodeoxy-elephantopin and scabertopin [8]. It also contains epifriedelinol, lupeol, stigmasterol [9], elephantopin and triterpenes [10]. The pharmacological properties of the leaf extracts have been evaluated for diuretic [11], anti-inflammatory [12], hepatoprotective [13] and antimicrobial activity [14]. In traditional claims, roots were used as an antipyretic, cardiotonic. Decoction of roots and leaves is used as emollient and given in dysuria, diarrhoea, dysentery, tonic, anthelmintic [15]. It is also used to treat stomachic pain [16] and also possesses hepatoprotective activity [17]. When the extracts of leaves are applied topically, they are employed as to treat eczema and ulcers [18], an antipyretic for treatment of erysipelas, skin infections, and measles [19]. In Siddha system of medicine, the leaves of this plant are used as a thaali for hair in case of hairfall, however, there is no scientific report available on hair growth promoting activity of Elephantopus scaber. Therefore, the present study was focused on the scientific investigation of the hair growth potential of Elephantopus scaber Linn. leaves.

\section{MATERIALS AND METHODS}

\section{Plant material}

Leaves of Elephantopus scaber Linn. were collected from local area of Bhopal, Madhya Pradesh, India in August 2011. The species was identified and authenticated at the Department of Botany, Jiwaji University, Gwalior, Madhya Pradesh, India, where a plant specimen was deposited. The collected leaves were air-dried, reduced to coarse powder using electric blender and stored in an airtight container at room temperature $\left(35^{\circ} \mathrm{C}\right)$. 


\section{Preparation of extract}

The dried coarse powder $(200 \mathrm{~g})$ of leaves was continuously extracted with methanol using Soxhlet apparatus for $48 \mathrm{~h}$. After complete extraction, the methanolic extract was concentrated under reduced pressure at $40^{\circ} \mathrm{C}$ in a vacuum dryer to obtain dried extract. The percent yield of the extract was found to be $8.74 \%(w / w)$.

\section{Preparation of herbal hair formulation}

Accurately weighed $2 \mathrm{~g}$ and $5 \mathrm{~g}$ of crude extract were taken and mixed in $100 \mathrm{ml}$ of oil base (olive oil) to prepare homogeneous mixture of $2 \%$ and $5 \%$ hair oil, respectively. Then, the prepared formulation was taken for further study to evaluate hair growth promoting activity.

\section{Animals}

Adult Wistar male albino rats (120-150 g) were used for the study. The experimental protocols used in this study were approved by the Institutional Animal Ethical Committee under CPCSEA (Regd. No 926/ab/06/CPCSEA). All animals were fed with standard laboratory diet and water ad libitum. They were housed in an air-conditioned room with 12:12 h light and dark cycle. The room temperature $\left(24 \pm 2^{\circ} \mathrm{C}\right.$ ) and humidity (about $60 \%$ ) were controlled automatically.

\section{Primary skin irritation test}

Small quantity of $2 \%$ and $5 \%$ prepared formulation was applied topically over the preselected area of all the animals and animals were observed for 48 hours for any symptoms of toxicity.

\section{Drug treatment}

The animals were divided into four groups (six animals in each group). Group I was kept as control group (only olive oil), Group II was treated as standard (2\% Minoxidil), Group III and IV were treated with $2 \%$ and $5 \%$ of formulation respectively. Hairs of $1-\mathrm{cm}^{2}$ area (dorsal portion) of all animals of each group were removed using hair remover cream to remove all hairs. The treated as well as standard groups (2\% Minoxidil) were treated with respective formulations on the denuded area of albino rats once a day for 30 days. The denuded area of rats of each group were unprotected due to free access of light and atmosphere. 


\section{In vivo hair growth analysis}

On completion of $30^{\text {th }}$ day treatment, the hair growth status of all the groups was observed visually and data were recorded.

\section{Qualitative analysis}

The qualitative analysis of hair growth was evaluated by visual observation of two abovementioned parameters. Initiation time (minimum time required to initiate hair growth) and completion time (minimum time required to cover the denuded skin region with new hair completely). Hair growth initiation and completion time was recorded for each group of animals and compared with control group [20-21].

\section{Quantitative analysis}

After 30 days of treatment, skin biopsies were taken from the shaved area and the specimens preserved in $10 \%$ formalin buffer [22-23]. Then the tissues were stained and allowed to microscopical analysis having ocular micrometer facility for determination of hair follicles in anagenic and telogenic phase.

\section{Hair length analysis}

The hair was plucked randomly from the shaved area of rats from each group. After $30^{\text {th }}$ day of the treatment, the length of ten hairs was measured and the average length was determined and compared with animals from control group [24].

\section{Hair weight analysis}

After 30 days, the rats of all the groups were sacrificed by cervical dislocation. Dorsal skin area $\left(1 \mathrm{~cm}^{2}\right)$ with hairs and without hairs was cut and weighed with the high precision analytical balance. After measuring, hair weight was calculated by subtracting weight of skin from weight of skin with hair [24].

\section{In vitro hair growth analysis}

\section{Hair follicular analysis}

The hair follicles were isolated from the neonates of albino rat. The neonates were sacrificed by cervical dislocation and the dorsal portion of the skin was dissected 
out and washed thoroughly in phosphate buffered saline. The skin was cut into small segments and individually placed in a Petri dish containing PBS. The segments were chopped thoroughly until the intact follicles came out from the skin. The intact hair follicles were isolated using a fine Pasteur pipette in binocular microscope. Individual, freshly isolated hair follicles were placed in separate wells of 96-well plates containing $150 \mu \mathrm{l}$ of Dulbecco's Modified Eagles Medium. Finally $1.5 \mu \mathrm{l}$ of $2 \%$ and $5 \%$ solution of methanolic extracts of $E$. scaber in dimethyl sulfoxide were added to the corresponding wells and the plates were maintained at $37^{\circ} \mathrm{C}$. After $24 \mathrm{~h}$ and $72 \mathrm{~h}$ of treatment, the status of hair follicle length was measured using a binocular microscope equipped with an eyepiece measuring graticule [25].

\section{Statistical analysis}

Data were expressed as mean \pm SEM. All data were analyzed statistically using one-way analysis of variance (ANOVA), followed by post-hoc Dunnet's test. Values of $p<0.05$ were considered statistically significant.

\section{RESULTS}

\section{Phytochemical analysis}

Phytochemical analysis revealed that methanolic extract of E. scaber contains flavonoids, steroids, tannins, terpenes and phenolic compounds.

\section{Skin irritation analysis}

MESL ( $2 \%$ and $5 \%$ oil formulation) did not show any sign of irritation i.e. no erythema or edema and no loss of hairs was observed at the site of application till 48 hours.

\section{In vivo hair growth measurement}

\section{Qualitative measurement of hair growth}

The times taken for hair growth initiation and completion were observed on shaved area at the end of the course in all the groups. As shown in table 1, the initiation of hair growth was observed on $11^{\text {th }}$ day in group-I, $7^{\text {th }}$ day in group-II, $10^{\text {th }}$ day in group-III and $8^{\text {th }}$ day in group-IV. Similarly, the completion of hair growth was found on $26^{\text {th }}$ day in group-I, $22^{\text {nd }}$ day in group-II, $25^{\text {th }}$ and $24^{\text {th }}$ day for group-III \& IV respectively. MESL ( $2 \%$ and 5\% formulation) showed significant $(p<0.01)$ hair growth activity as compared to control group. 
Table 1 .

Effect of MESL hair formulation on qualitative analysis of hair growth in rats.

\begin{tabular}{llcl}
\hline \multirow{2}{*}{ S. No. } & & \multicolumn{2}{c}{ Hair growth (days) } \\
\cline { 3 - 4 } & Treatment & Initiation time & Completion time \\
\hline 1 & Control & $11 \pm 0.577$ & $26 \pm 0.774$ \\
\hline 2 & Standard (2\% minoxidil solution) & $7 \pm 0.365^{* *}$ & $20 \pm 0.632 *$ \\
\hline 3 & $2 \%$ MESL & $10 \pm 0.577^{*}$ & $24 \pm 0.632^{*}$ \\
\hline 4 & $5 \%$ MESL & $8 \pm 0.577^{*}$ & $22 \pm 0.774^{*}$ \\
\hline
\end{tabular}

All values were expressed as mean \pm SEM; $n=6$ for each treatment group; MESL: methanolic extracts of Elephantopus scaber leaves; * $\mathrm{p}<0.01$ and ${ }^{* *} \mathrm{p}<0.001$ compared with control.

\section{Quantitative measurement of hair growth}

A considerable difference in cyclic phases of hair growth was observed in groups treated with minoxidil and MESL formulation. Cyclic phases of hair growth were markedly effected by the standard drug minoxidil and MESL. After 30 days of treatment, the anagenic population of hair follicles in group I, II, III and IV was found to be 51\%, 69\%, 59\% and 65\% respectively. Similarly, the telogenic population of hair follicles in group I, II, III and IV was found to be $49 \%, 31 \%, 41 \%$ and $35 \%$ respectively. Thus, both formulations in treated groups showed significant $(p<0.01)$ growth as compared to control. The results are summarized in table 2 .

Table 2 .

Effect of MESL hair formulation on the percentage of hair growth in different phases after 30 days of application in rats.

\begin{tabular}{|c|c|c|c|}
\hline S. No. & Treatment & $\%$ of Telogen & $\%$ of Anagen \\
\hline 1 & Control & $49 \pm 1.751$ & $51 \pm 1.732$ \\
\hline 2 & Standard ( $2 \%$ Minoxidil) & $31 \pm 1.807$ ** & $69 \pm 1.932$ 楼 \\
\hline 3 & $2 \%$ MESL oil & $41 \pm 1.932 * *$ & $59 \pm 1.932 *$ \\
\hline 4 & $5 \%$ MESL oil & $35 \pm 1.183$ *** & $65 \pm 2.017$ 橉 \\
\hline
\end{tabular}

All values were expressed as mean \pm SEM; $n=6$ for each treatment group; MESL: methanolic extracts of Elephantopus scaber leaves; " $p<0.01$ and $* 0.001$ compared with control.

\section{Hair length measurement}

The length of hair follicles was measured and observed that in group I, II, III and IV the length of hair follicles was $9 \pm 0.56 \mathrm{~mm}, 16 \pm 0.577 \mathrm{~mm}, 12 \pm 0.83 \mathrm{~mm}$ and $14 \pm 0.47 \mathrm{~mm}$, respectively. MESL treated group showed remarkable effect 
$(p<0.01)$ on length of hair follicles after 30-day treatment. The results are summarized in table 3 .

Table 3 .

Effect of MESL hair formulation on hair length after 30 days of application in rats

\begin{tabular}{llc}
\hline S. No. & Treatment & Hair length $(\mathrm{mm})$ \\
\hline 1 & Control & $9 \pm 0.557$ \\
\hline 2 & Standard (2\% Minoxidil) & $16 \pm 0.577^{\text {***** }}$ \\
\hline 3 & $2 \%$ MESL & $12 \pm 0.830$ \\
\hline 4 & $5 \%$ MESL & $14 \pm 0.471^{\text {粎 }}$ \\
\hline
\end{tabular}

All values were expressed as mean \pm SEM; $n=6$ for each treatment group; MESL: methanolic extracts of Elephantopus scaber leaves; * $\mathrm{p}<0.01$ and ${ }^{* * *} \mathrm{p}<0.001$ compared with control.

\section{Hair weight measurement}

The weight of newly grown hairs in the test groups and standard group were measured and compared with control group. The weight of hair was significantly $(p<0.05)$ increased, found to be 53 and $58 \mathrm{mg} / \mathrm{cm}^{2}$ area of dorsal skin for $2 \%$ and $5 \%$ of MESL hair oil formulation, respectively. Whereas, minoxidil was found to be $53 \mathrm{mg} / \mathrm{cm}^{2}$ area of dorsal skin of rat (tab. 4).

Table 4 .

Effect of MESL hair formulation on hair weight after 30 days of application in rats

\begin{tabular}{llc}
\hline S. No. & Treated groups & Weight of hair $(\mathrm{mg} / \mathrm{cm} 2)$ \\
\hline 1 & Control group & $49 \pm 2.781$ \\
\hline 2 & Standard (2\% Minoxidil) & $59 \pm 1.807^{* * * *}$ \\
\hline 3 & $2 \%$ MESL & $53 \pm 0.577$ \\
\hline 4 & $5 \%$ MESL & $58 \pm 1.202^{* * * *}$ \\
\hline
\end{tabular}

All values were expressed as mean $\pm S E M ; n=6$ for each treatment group; MESL: methanolic extracts of Elephantopus scaber leaves; ${ }^{*}$ 粠 $\mathrm{p}<0.001$ compared with control.

\section{In vitro hair growth measurement}

As shown in table 5, the growth of hair follicle was observed under binocular microscope at higher magnification. The MESL in both dose groups showed a significant $(p<0.05)$ increase in length over $72 \mathrm{~h}$ in culture against control group $(0.13 \mathrm{~mm} / \mathrm{d})$. The rate of growth was found to be $0.28 \pm 0.02 \mathrm{~mm}$ and $0.37 \pm 0.02$ $\mathrm{mm}$ per $72 \mathrm{~h}$ in $2 \%$ and $5 \%$ MESL treated group, respectively. 
Effect of hair formulation MESL on in vitro hair follicle culture

\begin{tabular}{llcc}
\hline \multirow{2}{*}{ S. No. } & Treated groups & \multicolumn{2}{c}{ Increase in hair follicle length $(\mathrm{mm})$} \\
\cline { 3 - 4 } & & After $24 \mathrm{~h}$ & After $72 \mathrm{~h}$ \\
\hline 1 & Control group & $0.09 \pm 0.018$ & $0.13 \pm 0.014$ \\
\hline 2 & DMSO & $0.04 \pm 0.008$ & $0.08 \pm 0.014$ \\
\hline 3 & $2 \% \mathrm{MESL}$ & $0.13 \pm 0.017^{*}$ & $0.28 \pm 0.023^{*}$ \\
\hline 4 & $5 \% \mathrm{MESL}$ & $0.17 \pm 0.020^{*}$ & $0.37 \pm 0.017^{*}$ \\
\hline
\end{tabular}

All values were expressed as mean $\pm S E M ; n=6$ for each treatment group; MESL: methanolic extracts of Elephantopus scaber leaves; * $\mathrm{p}<0.01$ compared with control.

\section{DISCUSSION}

Methanolic extract of Elephantopus scaber hair oil formulation on topical application stimulate the hair growth initiation and completion time. It was observed that the hair growth initiated from the shaved area at the start of the $2^{\text {nd }}$ week in all groups, including control, and in the whole denuded area has been covered at the end of the course, in comparison to the control. This may be due to gentle rubbing of the shaved skin while application of extracts. This enhances the blood circulation in local area. Thus, it may exert some effect on hair growth. Androgenetic alopecia is a dihydrotestosterone-mediated process characterized by continuous miniaturization of androgen-reactive hair follicles and accompanied by perifollicular fibrosis of follicular units in histological examination [26, 6]. Retention of late anagenic follicles as well as increase in follicular length and prevention of miniaturization. Therefore, it may be attributed to 5 - $\alpha$-reductase inhibitory activities. The groups treated with formulation produced a greater effect on the length of hair as compared to control group. This may be due to the premature switching of follicles from telogen to anagen phase of hair growth cycle [25]. The in vitro study revealed that the leaf extract has direct impact on hair follicles and thus may improve the hair growth. It is expected that several fatty acids, e.g. palmitic, oleic, linoleic, linolenic and arachidonic acids, as well as mixture of these acids show a significant anti-androgenic effect owing to their testosterone 5 - $\alpha$-reductase inhibitory activity [27, 24]. Flavonoids and triterpenoids possess hair growth promoting activity by strengthening the capillary wall of smaller blood vessels supplying hair follicles, improve blood circulation to nourish the hair follicles and thereby promote the hair growth $[28,25]$. Flavonoids play a great role by stimulating telogen to anagen phase, a process involved in hair growth, and also cause expressions of some growth factors, such as insulin-like growth factor-1(IGF-1), vascular endothelial growth factors (VEGF), keratinocyte growth factors (KGF) and hapatocyte growth factors (HGF), 
all of which has a stimulatory effects on hair growth [29-31]. Minerals and certain amino acids may be the cause for the significant hair growth activity which not only shows remarkable activity but also devoid of potential side effects as compared to synthetic drugs [32].

Methanolic extract and its water insoluble fraction of green tea showed the presence of phenolic compounds. The EGCG (epigallocatechin-3-gallate), a major constituent of polyphenols of green tea was reported to be useful in the treatment of androgenetic alopecia by selectively inhibiting 5 - $\alpha$-reductase activities [33].

\section{CONCLUSIONS}

In conclusion, the experimental evidence obtained in present laboratory animal study indicates that metahnolic extract of Elephantopus scaber leaves possesses hair growth promoting effect. This may be due to the presence of triterpenes, polyphenols and flavonoids in the plant extracts. Further pharmacological and biochemical investigations needed to establish the mechanism of action and isolation of phytoconstituents from the extract may provide new directions for the better treatment of alopecia or hair loss.

\section{ACKNOWLEDGEMENTS}

Authors are grateful to Ayushmati Education and Social Society, Bhopal, Madhya Pradesh, India for financial support during the study.

\section{REFERENCES}

1. Vera HP. Treatment of hair loss. New Engl J Med 1999; 341:964-973.

2. Bhalearo SS, Salanki NH. Therapeutics approaches to the management of common baldness. Indian Drugs 2002; 39:567-573.

3. Sharma M, Banerjee PS. Preparation and evaluation of mixed herbal hair oil formulation. Phcog J 2009; 1:154-160.

4. Purwal L, Gupta SPBN, Pande MS. Development and Evaluation of Herbal Formulations for Hair Growth. E-Journal of Chemistry 2008; 5:34-38.

5. Kevin JME, Rodney S. Hair physiology and its disorders. Drug Discovery Today: Disease Mechanisms 2008; 5: e163-e171.

6. Yoo HG, Kim JS, Lee SR, Pyo HK, Moon HI, Lee JH, Kwon OS, Chung JH, Kim KH, Eun HC, Cho KH. Perifollicular fibrosis: pathogenetic role in androgenetic alopecia. Biol Pharm Bull 2006; 29:1246-1250.

7. Bhaumik S, Jyothi MD, Khar A. Differential modulation of nitric oxide production by curcumin in host macrophages and NK cells. FEBS Lett 2000; 483:78-82.

8. Paul PHB, Po-Ming H, Hui C, Dominic Chan TW, Bo-Mu W, Thomas CWM, Chun-Tao C. Sesquiterpenes lactone from Elephatopus scaber. Phytochemistry 1997; 44: 113-116.

9. De Silva LB, Hearth WHMW, Jennings RC, Mahendran M, Wannigamma GE. A new sesquiterpene lactone from Elephatopus scaber. Phytochemistry 1982; 21:1173-1175. 
10. Rajkapoor B, Jayakar B, Anandan R. Antitumor activity of Elephantopus scaber Linn. Against Dalton's Ascitic Lymphoma. Indian J Pharm Sci 2002; 64:71-73.

11. Poli A, Nicolau M, Simoes CM, Nicolau RM, Zanin M. Preliminary pharmacologic evaluation of crude whole plant extracts of Elephantopus scaber. Part I: in vivo studies. J Ethnopharmacol 1992; 37:71-76.

12. Tsai CC, Lin CC. Anti-inflammatory effects of Taiwan folk Medicine 'Teng Khai U' on carrageenan and adjuvant induced paw edema in rats. J Ethnopharmacol 1999; 64: 85-89.

13. Lin CC, Tsai CC, Yen MH. The evaluation of hepatoprotective effects of Taiwan folk medicine 'Teng Khai U'. J Ethanopharmacol 1995; 45:113-123.

14. Rao GB, Rao YV, Pavani S, Dasari VSP. Qualitative and quantitative phytochemical screening and in vitro anti oxidant and anti microbial activities of Elephantopus scaber Linn. Recent Research in Science and Technology 2012; 4(4):15-20.

15. Burkhkl H. Dictionary of the Economic Products of the Malay Peninsula. Vol-I. Singapore: Government Printing Press, 1935, 909.

16. Kiritikar KD, Basu BD. Indian Medicinal Plants. New Delhi, India: Periodical Experts Books Agency, 1991.

17. Lin JK, Tsai SH, Lin-Shiau SY. Anti inflammatory and anti tumor effects of flavonoids and flavanoids. Drug Future 2001; 26: 145-157.

18. Chopra RN, Nayak SL, Chopra IC. Glossary of Indian Medicinal Plants. Delhi: CSIR, 1956.

19. Morton J. Atlas of Medicinal Plants of Middle America, Bahamas to Yucatan. Springfield, IL: Thomas, $1981,420$.

20. Adhirajan N, Dixit VK, Chandrakasan G. Development and evaluation of herbal formulations for hair growth. Indian drugs 1999; 38: 559-563.

21. Roy RK, Thakur M, Dixit VK. Development and evaluation of polyherbal formulation for hair growth promoting activity. J Cosmet Dermatol 2007; 6:108-112.

22. Roy RK, Thakur M, Dixit VK. Hair growth promoting activity of Eclipta alba in male albino rats. Arch Dermatol Res 2008; 300: 357-364.

23. Datta K, Singh AT, Mukherjee A, Bhat B, Ramesh B, Burman AC. Eclipta alba extract with potential for hair growth promoting activity. J Ethnopharmacol 2009; 124: 450-456.

24. Yoon JI, Al-Reza SM, Kang SC. Hair growth promoting effect of Zizyphus jujuba essential oil. Food Chem Toxicol 2010; 48: 1350-1354.

25. Adhirajan N, Ravi Kumar T, Shanmugasundaram N, Babu M. In vivo and in vitro evaluation of hair growth potential of Hibiscus rosa-sinensis Linn. J Ethnopharmacol 2003; 88: 235-239.

26. Roy RK, Thakur M, Dixit VK. Effect of Citrullus coclocynthis Schrad. on hair growth activity of albino rats. Aust J Med Herbal 2007; 6: 108-112.

27. Liang T, Liao S. Growth suppression of hamster flank organs by topical application of c-linolenic and other fatty acid inhibitors of 5a-reductase. J Invest Dermatol 1997; 109: 152-157.

28. Kobayashi N, Suzuki R, Koide C, Suzuki T, Matsuda H, Kubo M. Effect of leaves of Ginkgo biloba on hair regrowth in C3H strain mice. Yakugaku Zasshi 1993; 113: 718-724.

29. Takahashi T, Kamiya T, Hasegawa A, Yokoo Y. Procyanidin oligomers selectively and intensively promote proliferation of mouse hair epithelial cells in vitro and activate hair follicle growth in vivo. J Invest Dermatol 1999; 112: 310-316.

30. Roh SS, Kim CD, Lee MH, Hwang SL, Rang MJ, Yoon YK. The hair growth promoting effect of Sophora flavescens extract and its molecular regulation. J Dermatol Sci 2002; 30: 43-49.

31. Awe EO, Makinde JM. The hair growth promoting effect of Russelia equisetiformis (Schclect \& Chan). J Nat Prod 2009; 2: 70-73.

32. Banerjee PS, Sharma M, Nema RK. Preparation, evaluation and hair growth stimulating activity of herbal hair oil. J Chem Pharm Res 2009; 1: 261-267.

33. Kwon OS, Han JH, Yoo HG, Chung JH, Cho KH, Eun HC, Kim KH. Human hair growth enhancement in vitro by green tea epigallocatechin-3-gallate (EGCG). Phytomedicine 2007; 14: 551-555. 
WSTĘPNE BADANIE WPŁYWU WYCIĄGU METANOLOWEGO Z ELEPHANTOPUS SCABER LINN. NA PROCES WSPOMAGANIA WZROSTU OWŁOSIENIA U SZCZURÓW

\section{HIMANSHU BHUSAN SAHOO ${ }^{2}$, RAKESH SAGAR ${ }^{1 *}$, SUBRAT KUMAR BHATTAMISRA ${ }^{3}$, AMRITA BHAIJI ${ }^{2}$}

${ }^{1}$ Department of Pharmacognosy and Phytochemistry

Dr. H.S. Gour Central University

Sagar, 470003

Madhya Pradesh, India

${ }^{2}$ Department of Pharmacology and Toxicology

Vedica College of Pharmacy

Bhopal 462021

Madhya Pradesh, Indie

${ }^{3}$ Department of Pharmacology

Roland Institute of Pharmaceutical Sciences

Berhampur 760010

Orissa, Indie

*autor, do którego należy kierować korespondencję: e-mail: drrsagar@gmail.com

Streszczenie

Badano wpływ wyciągu metanolowego z liści Elephantopus scaber na wzrost włosów u szczurów laboratoryjnych. Przez 30 dni badano wzrost włosów u szczurów Wistar po podaniu 2\% i 5\% preparatu sporządzonego z użyciem ekstraktu metanolowego. Substancją kontrolną był minoksidil (roztwór $2 \%$ ). Preparat z ekstraktu metanolowego przygotowany na bazie oleju istotnie $(p<0,01)$ zwiększał inicjację wzrostu włosów i przyspieszał jego zakończenie. Podczas biopsji odnotowano też zależną od dawki poprawę stanu skóry, długości włosów i zwiększenie masy włosów. Podczas badaniu in vitro wykazano istotną $(p<0,05)$ poprawę tworzenia się nowych mieszków włosowych. Powyższe wyniki wskazują, że wyciąg metanolowy z E. scaber może istotnie zwiększać porost włosów.

Słowa kluczowe: tysienie, wzrost włosów, Elephantopus scaber, minoksidil 